\title{
Penguatan Kelembagaan BUM Desa Menuju Kekuatan Baru Ekonomi Indonesia
}

\author{
Erry Setyo Prabowo ${ }^{1)} \mid$ Eko Wiratno $^{2)} \mid$ Suparto $^{3)}$ \\ 1,2,3) Sekolah Tinggi Ilmu Administrasi Madani \\ ekowiratno@stiamadani.ac.id
}

\begin{abstract}
Abstrak: Bidang perekonomian yang ada di Kabupaten Klaten, Jawa Tengah mayoritas adalah di sektor pertanian yang mempunyai basis di pedesaan, namun pertumbuhannya bisa dikatakan kurang maksimal atau sangat lamban sekali. Usaha dari pemerintah dalam mengentaskan kemiskinan dilakukan dan dilaksanakan dengan memberikan keputusan yang baik bagi pemerintah yang berada ditingkat paling bawah yang dalam hal ini adalah Pemerintahan Desa(Pem Des). Upaya itu tercetus dalam sebuah badan yang disebut dengan Badan Usaha Milik Desa yang disingkat dengan BUM Desa. BUM Desa sendiri merupakan badan usaha yang seluruh atau sebagian permodalannya berasal dari desa dengan prosentasi minimal 51\%. Modal yang disisihkan nantinya bisa dimanfaatkan untuk menciptakan lapangan pekerjaan ataupun meningkatkan pelayanan masyarakat yang baik sehingga diharapkan bisa menembah kesejahteraan warga desa dan tentunya menambah Pendapatan Asli Desa(PAD) seperti dari tujuan didirikannya BUM Desa tersebut. Faktor penyebab kurang berhasilnya program-program tersebut paling dominan adalah daya kreativitas dan inovasi masyarakat desa dalam mengelola dan menjalankan mesin ekonomi di pedesaan yang masih rendah yang dalam hal ini masih sedikit adanya pelatihan atau penyuluhan yang diadakan untuk mendukung majunya BUM Desa sehingga sistem dan mekanisme kelembagaan ekonomi di pedesaan yang awalnya tidak berjalan efektif bisa terlaksana dengan baik. Peran strategis kampus dengan para akademisinya tentu saja bakal menjadi amunisi yang sangat strategis bagi desa-desa di Kabupaten Klaten sehingga bisa menemukan solusi dan rumusan proses yang lebih cepat menuju desa sejahtera, desa yang maju, desa yang mandiri, desa yang bisa berdaya saing dan desa yang bisa memberi masukan PAD. Di sisi lain, wacana ekonomi desa khusu snya BUM Desa pasca Undang-Undang Omnibus Law juga bakal mendorong para akademisi mengkaji lebih jauh berbagai potensi ekonomi desa yang hingga hari ini masih butuh banyak dukungan, Indonesia akan menjadi maju dan kuat ekonominya jika dimulai dari desa. Dan desa adalah ikon pembangunan nasional yang mencerminkan pembangunan menyeluruh.
\end{abstract}

Kata Kunci: Kelembagaan, Bum Desa, Ekonomi

\section{Pendahuluan}

Perguruan Tinggi mengemban amanah Tri Darma Perguruan Tinggi yang meliputi bidang pengajaran, penelitian dan pengabdian kepada masyarakat. Dalam program pengabdian masyarakat ini khalayak sasaran yang akan kita dampingi adalah program masyarakat yang produktif secara ekonomi. Desa yang kita dampingi kali ini sangat berharap bekerjasama dengan Perguruan Tinggi untuk melakukan penguatan kelembagaan BUM Desa sehingga diharapkan menjadi sebuah kekuatan ekonomi baru didesa dan sebagai mitra yaitu BUM Desa yang ada di Desa Gempol, Kecamatan Karanganom, Kabupaten Klaten, Jawa Tengah untuk menjadi venue bagi kekuatan ekonomi desa untuk proses produksi, distribusi, sekaligus pemasaran yang nantinya diharapkan bisa memajukan masyarakat di desa yang kita dampingi. Melalui kehadiran BUMDes ini diharapkan desa menjadi lebih mandiri dan masyarakatnya pun menjadi lebih sejahtera (Sujarweni dan Jaya, 2019). Pada kenyataanya tidaklah mudah dalam mengembangkan BUM Desa di desa. 
Berbagai permasalahan yang dihadapi BUM Desa menjadi tantangan tersendiri yang harus dihadapi dalam memajukan BUM Desa. Beberapa permasalahan BUM Desa antara lain permasalahan komunikasi diantara pengurus, pengelolaan unit usaha, masalah personil, dan potensi desa yang belum dapat dimanfaatkan (Nugraha \& Kismartini, 2019). Permasalahan pengelolaan BUMDes dibeberapa daerah antara lain jenis usaha yang dijalankan masih terbatas, keterbatasan sumber daya manusia yang mengelolan BUMDes dan partisipasi masyarakat yang rendah karena masih rendahnya pengetahuan mereka (Agunggunanto, Arianti, Kushartono \& Darwanto, 2016). Selain itu, unit usaha BUM Desa belum mampu memberdayakan masyarakat dan mengurangi tingkat pengangguran karena total penyerapan tenaga kerja dari unit-unit usaha BUM Desa masih sedikit, walaupun omzet BUM Desa sudah bagus namun profit yang diperoleh masih sangat kecil sehingga belum mampu memberikan kontribusi terhadap Pendapatan Asli Desa (Hidayah, Mulatsih, \& Purnamadewi, 2019). Hasil penelitian Suwencantara Surya dan Riady (2018) menunjukkan, efektivitas pengelolaan BUM Desa belum memberikan kontribusi berupa pendapatan asli desa kepada pemerintah desa. Dari tiga indikator efektivitas yang digunakan yaitu pencapaian tujuan, integrasi, dan adaptasi belum semua tercapai. Kendala utama yang dihadapi antara lain penyertaan modal dan keterbatasan Sumber Daya Manusia (SDM). Berdasarkan kondisi tersebut perlu adanya strategi pengelolaan yang sesuai dengan kondisi BUM Desa disuatu daerah agar BUM Desa dapat berkontribusi dalam memajukan perekonomian dan meningkatkan kesejahteraan masyarakat desa. Dalam perkembangannya, realita penggunaan dana desa tidak tepat peruntukkannya, dampak yang sangat menonjol dalam pengelolaan dan penggunaan dana desa adalah desa dengan kewenangannya cenderung "berdiri sendiri" dan daerah kesulian mengintegrasikan antara program desa dengan kebijakan daerah (Jamaluddin, Sumaryana, Rusli \& Buchari, 2018).

Permasalahan utama yang dihadapi oleh BUM desa yang ada di Desa Gempol selama ini adalah (1). Belum ada struktur Organisasi yang jelas di desa sehingga belum bisa berkembang. (2). Belum jelas program kerja BUM Desa karena pengurus belum memahami tugas dan pokok dari masingmasing pengurus. Peningkatan perekonomian desa hendaknya dimulai dengan memberikan legalitas yang tepat sehingga BUMDes benarbenar membuktikan perannya sebagai salah satu upaya dalam meningkatkan Pendapatan Asli Desa (PADes) serta menumbuhkan perekonomian desa secara utuh dan menyeluruh (Dewi, 2014) (3). Belum disediakan lahan untuk kantor BUM Desa yang representatif, Kantor masih dopleng dengan balai desa jadi terkesan tidak memadai. (4). Rencana penguatan kelembagaan ekonomi desa berbasis ekonomi kolaboratif yang belum terarah dengan baik dan belum mampu diakomodir secara baik oleh pemerintah sehingga membutuhkan pendampingan dari berbagai pihak baik dari pemerintah, swasta, Perguruan Tinggi maupun lembaga-lembaga yang peduli dengan BUM Desa.

Kendala lain yang dihadapi adalah pertama dari sisi pengembangan kelembagaan ekonomi desa dengan perencanaan awal yang tepat dalam penentuan usulan program atau kegiatan khususnya untuk kelompok usaha agar mampu meningkatkan sumber pendapatan, pengetahuan dan keterampilan masyarakat melalui pelaksanaan program-program pelatihan dan penguatan kelembagaan ekonomi desa. Kedua, dari sisi pengembangan perlunya perencanaan awal dari masyarakat untuk menguatkan lembaga ekonomi di desa dengan berbagai potensi-potensi yang ada dan yang dimiliki oleh desa dan masyarakat, serta perlunya sosialisasi pemerintah desa dan instansi terkait dalam rangka menciptakan kekuatan ekonomi baru di desa dalam wadah Badan Usaha Milik Desa tersebut.

Pengabdian pada masyarakat kali ini sebagai bagian dari Tri Darma Perguruan Tinggi, merasa terpanggil untuk ikut membantu memberikan solusi terhadap permasalahan yang dihadapi di Desa Gempol, Kecamatan Karanganom, Kabupaten Klaten. Melalui pengabdian pada masyarakat kali ini dan berdasarkan analisis kebutuhan yang telah dilaksanakan, tim menawarkan solusi terhadap permasalahan tersebut dengan beberapa sentuhan-sentuhan yang diharapkan bisa berjalan dengan efektif dan efisien antara lain yaitu : Penguatan kelembagaan BUM Desa menjadi kekuatan baru ekonomi di Desa yang bisa maju, Penyiapan sarana dan prasarana pengembangan potensi desa, Sosialisasi kepada masyarakat, Manajemen pemasaran produk desa. 
Tabel 1. Target Luaran Pengabdian pada Masyarakat BUMDes

\begin{tabular}{|r|l|l|l|}
\hline No & \multicolumn{1}{|c|}{ Produk } & \multicolumn{1}{|c|}{ Spesifikasi } & \multicolumn{1}{|c|}{ Target } \\
\hline 1. & Penguatan Kelembagaan & BUM Desa & $\begin{array}{l}\text { Kelompok Usaha } \\
\text { Ekonomi }\end{array}$ \\
\hline 3. & Manajemen pengelolaan & $\begin{array}{l}\text { Manajemen usaha yang } \\
\text { Teratur, tertib } \\
\text { jasa pelayanan } \\
\text { konsumen }\end{array}$ & Potensi desa \\
\hline 4. & $\begin{array}{l}\text { Peningkatan pengetahuan pengurus } \\
\text { BUM Desa bersama tata kelola } \\
\text { BUM Desa }\end{array}$ & Pengurus BUM Desa & Standarisasi mutu \\
\hline 5. & $\begin{array}{l}\text { Pendampingan, pelatihan } \\
\text { dan workshop }\end{array}$ & Pengurus BUM Desa & $\begin{array}{l}\text { Inovasi dan } \\
\text { pemanfaatan } \\
\text { teknologi }\end{array}$ \\
\hline
\end{tabular}

\section{Metode Pelaksanaan}

Metode yang ditawarkan untuk menyelesaikan persoalan BUM Desa yang ada di Desa Gempol, Kecamatan Karanganom, Kabupaten Klaten adalah program yang telah disepakati bersama yakni menggunakan metode pelatihan dan pendampingan, secara teknis metode yang digunakan adalah Metode Focus Group Discussion dan metode pendampingan dimana dalam kegiatan ini peserta mitra program yaitu BUM Desa dan masyarakat di Desa Gempol, Kecamatan Karanganom, Kabupaten Klaten menjadi pelaku utama dalam rangka mencapai tujuan kegiatan pelatihan.

Dalam implementasi metode dilapangan, masyarakat menjadi pelaku utama dalam merancang dan menganalisis potensi dan persoalan mereka untuk tujuan menciptakan produk-produk inovatif yang akan memberi nilai tambah dan daya saing yang lebih tinggi, sehingga ekonomi didesa bisa berkembang.Salah satu prioritas penggunaan dana desa adalah untuk BUM Desa, perlu peran aktif dari pemerintah desa dalam hal ini. Keterlibatan pemerintah desa menjadi peran utama sebagai penggerak pembangunan desa dalam bentuk partisipasi sebagai tolak ukur kemampuan dan keterlibatan desa dalam pengembangan BUM Desa di daerah yang bersangkutan (Asti \& Cholid, 2018). Pertumbuhan BUM Desa diberbagai daerah di Indonesia sangat signifik

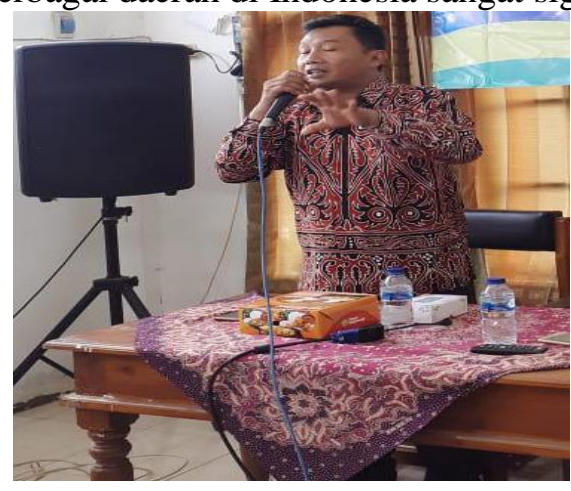

(a)

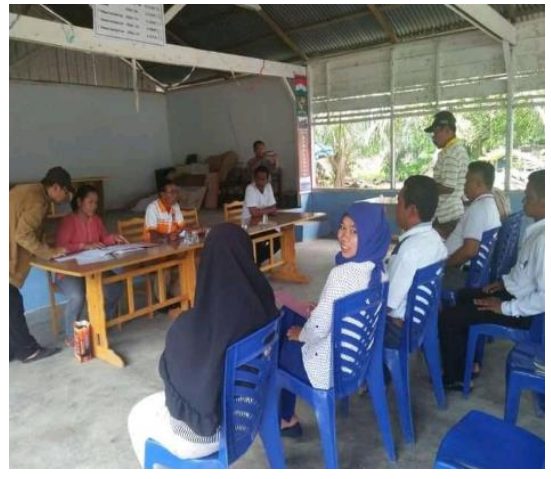

(b) 


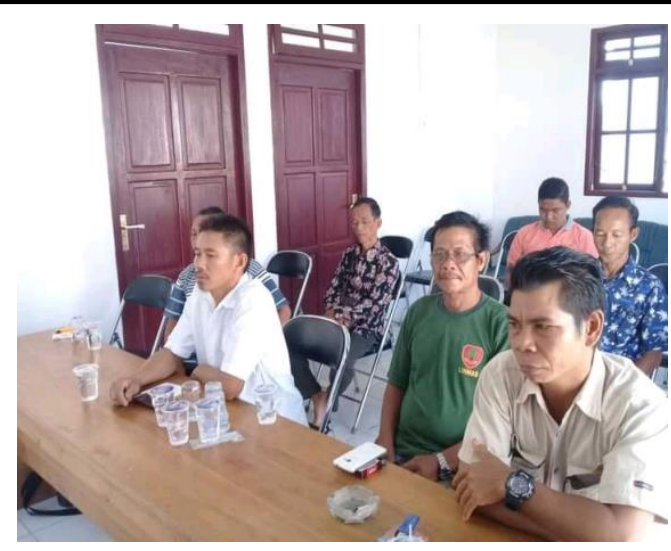

(c)

Gambar 1. Suasana Pengabdian Masyarakat di Desa Gempol, Karanganom, Klaten.

\section{Hasil}

Hasil kegiatan yang dilakukan Tim di Desa Gempol, Kecamatan Karanganom, Kabupaten Klaten adalah salah satunya pembentukan BUM Desa dengan tujuan: 1. Menumbuh kembangkan perekonomian desa(standar pelayanan minimal); 2. Meningkatkan Sumber Pendapatan Asli Desa, mengurangi kemiskinan, pengangguran; 3 . Menyelenggarakan kemanfaatan umum berupa penyediaan jasa bagi peruntukan hajat hidup masyarakat desa; 4. Sebagai perintis bagi kegiatan usaha di desa.

Sedangkan tujuan pembentukan BUMDes antara lain: 1. Meningkatkan peranan masyarakat desa dalam mengelola sumber-sumber pendapatan lain yang sah; 2. Menumbuhkembangkan kegiatan ekonomi masyarakat desa, dalam unit-unit usaha desa; 3 . Menumbuhkembangkan usaha sektor informal untuk dapat menyerap tenaga kerja masyarakat di desa; 4. Meningkatkan kreatifitas berwira usaha Desa masyarakat desa yang berpenghasilan rendah Pendirian dan pengelolaan Badan Usaha Milik Desa (BUMDes) adalah merupakan perwujudan upaya memaksimalkan peran pengelolaan ekonomi produktif desa yang selama ini dilakukan oleh pemerintah desa. Peran ini perlu dilakukan secara kooperatif, partisipatif, emansipatif, transparansi, akuntabel, dan sustainable agar nantinya pengelolaan BUM Desa tersebut dapat berjalan secara efektif, efisien, profesional dan mandiri.

\section{Pembahasan}

Berdasarkan hasil penelusuran tim dosen di lokasi kegiatan Pengabdian masyarakat, terlihat kebanyakan masyarakat masih kurang memahami tentang BUM Desa, tugas dan fungsinya serta perannya dalam memberdayakan masyarakat bidang ekonomi produktif, sehingga mengakibatkan kurang pedulinya pada upaya mendirikan lembaga BUM Desa, hal inilah yang didapatkan oleh tim dosen selama melakukan penelusuran pendapat masyarakat terkait pemahamannya tentang BUM Desa, yang kebanyakan masyarakat bertanya balik kepada kami untuk mengetahui tentang maksud dan tujuan lembaga tersebut. Kurangnya sosialisasi yang dilakukan oleh pemerintah desa menambah permasalahan akan rencana pembentukan BUM Desa padahal lembaga yang bergerak di bidang kewirausahaan ini telah menjadi amanat dari Undang-Undang Nomor 6 Tahun 2014 tentang Desa Pasal 1 Ayat (6) berbunyi : "BUMDesa adalah Badan usaha yang seluruh atau sebagian besar modalnya dimiliki oleh Desa melalui penyertaan secara langsung yang berasal dari kekayaan Desa yang dipisahkan guna mengelola aset, jasa pelayanan, dan usaha lainnya untuk sebesar-besarnya kesejahteraan masyarakat Desa".

Berdasarkan Undang-Undang Desa bahwa BUM Desa sangatlah berperan sekali dan sangat penting untuk mewujudkan kesejahteraan masyarakat desa melalui pembentukan unit-unit usaha yang dapat mengembangankan potensi-potensi lokal yang dimiliki oleh desa tersebut, dengan pembentukan 
BUM Desa diharapkan dapat memacu semangat masyarakat desa untuk memaksimalkan pemanfaatan sumber daya yang dimiliki untuk kemakmuran bersama.

Kehadiran tim yang dilibatkan dalam kegiatan pengabdian kepada masyarakat telah membuka pemahaman baru bagi pemerintah desa, BPD maupun masyarakat Desa Gempol, Kecamatan Karanganom, Kabupaten Klaten melalui kegiatan identifikasi potensi lokal kepada beberapa warga desa untuk mengetahui tingkat pemahaman warga tentang BUM Desa, dalam kegiatan pendataan tersebut kami menyiapkan pedoman wawancara serta dokumen yang diperlukan. Selama kegiatan mencari informasi dari warga terkait rencana pembentukan BUM Desa, kebanyakan warga tidak tahu tentang makna BUM Desa dan pentingnya bagi peningkatan ekonomi masyarakat.

Materi yang ditampilkan disesuaikan dengan kondisi dan potensi yang ada di Desa Gempol dengan mendayagunakan para petani lokal dengan mengikutkan mereka dalam kepengurusan BUM Desa yang dibentuk dalam unit-unit usaha masing-masing petani, misalnya pentingnya pembentukan BUM Desa setidaknya ada tiga manfaat yaitu:

1. Untuk tempat pelayanan publik artinya BUM Desa yang dibentuk diharapkan dapat meningkatkan pelayanan kepada para petani di Desa Gempol misalnya pemenuhan kebutuhan puput, bibit, alat-alat pertanian maupun alat penangkal hama yang merupakan tuntutan para petani, yang selama ini masih menjadi kendala dalam usaha pertanian mereka.

2. Mengefektifkan pembangunan desa artinya pendirian BUM Desa diharapkan dapat memberikan kesempatan kepada masyarakat untuk ikut serta dalam menentukan kebutuhan prioritas sesuai dengan potensi desa selama ini, dengan berdirinya lembaga yang bergerak di bidang wirausaha ini akan menunjang peningkatan pendapatan para petani dan ibu-ibu yang bergerak di Usaha Mikro Kecil Menengah(UMKM) dengan mengalokasi dana desa sesuai dengan kesepakatan antara pengurus BUM Desa, Pemerintah Desa, BPD dan masyarakat desa secara umum.

3. Meningkatkan kapasitas pemerintah desa menuju desa mandiri artinya BUM Desa dapat memberikan peluang-peluang bagi pemerintah desa untuk mewujudkan pendapatan asli desa(PAD) secara mandiri tanpa mengharapkan banyak bantuan dari pemerintah desa maupun pusat. Seperti halnya desa-desa lain yang sudah cukup sukses mengelolaan dana desa hingga dapat menghasilkan PAD, dengan pendapatan asli desa yang memadai tersebut akan dapat membantu sektor lainnya.

Berdasarkan pernyataan di atas bahwa upaya mendirikan BUM Desa yang selama ini masih diabaikan oleh pemerintah desa diharapkan dapat memberikan manfaat sesuai dengan amanat peraturan perundang-undangan karena kondisi warga Desa Gempol, Kecamatan Karanganom, Kabupaten Klaten banyak berpenghasilan menengah ke bawah dapat diberikan bantuan berupa uang maupun barang yang dapat digunakan untuk meningkatkan usaha masyarakat dalam pengelolaan potensi ekonomi desanya, disamping itu dengan adanya BUM Desa akan membuka lapangan pekerjaan baru bagi warga dengan melibatkannya dalam kepengurusan BUM Desa maupun menjadi bagian dari unit usaha yang bergerak di bidang pertanian maupun UMKM.Upaya BUMDes ini agar dapat berkembang dan menjadi lembaga perekonomian desa yang berdaya saing, maka perlu adanya kategorisasi tingkat perkembangan BUMDes berdasarkan status perkembangannya, dimana kategorisasi ini dapat membantu pemerintah dalam pengambilan keputusan (Febriyani et al., 2019). Eksistensi atau penguatan peran BUMDes dalam mengembangkan usaha dan perekonomian masyarakat desa memerlukan penanganan yang komprehensif, sehingga tumbuhnya ekonomi nasional ditopang kokoh oleh perekonomian desa yang kokoh dan terarah, maka berikut beberapa saran penulis sebagai rekomendasi kepada berbagai pihak (Harmati \& Zulhakim, 2018).

Ada beberapa hal yang sangat dibutuhkan dalam menguatkan Lembaga BUM Desa yang rencana akan dibentuk di Desa Gempol, Kecamatan Karanganom, Kabupaten Klaten yaitu:

1. Meningkatkan kualitas sumber daya manusia dengan mengikutkan dalam berbagai pelatihan kelembagaan, pelatihan pengelolaan dan berbagai pelatihan lainnya yang berhubungan dengan tugasnya dalam meningkatkan produktivitas pertanian maupun menambah pendapatan UMKM.

2. Peningkatan serta pemanfaatan teknologi tepat guna.

3. Pembangunan infrastruktur dengan menyediakan infrastruktur dasar. 


\section{Kesimpulan}

Masih kurangnya pemahaman masyarakat tentang BUM Desa yang ada Desa Gempol, Kecamatan Karanganom, Kabupaten Klaten dikarenakan kurangnya sosialisasi yang dilakukan pemerintah desa sehingga dari tahun 2015 sampai 2019 masih fokus pembangunan fisik tanpa membentuk BUM Desa yang seharusnya sudah lama terbentuk. Adanya potensi desa yang bisa dikembangkan dengan menggunakan dana desa yaitu lahan pertanian dan perkebunan yang cukup luas serta usaha UMKM yang kebanyakan digeluti oleh perempuan. Dengan didukung masyarakat, pemerintah desa, dan BPD dalam rencana pembentukan BUM Desa setelah para dosen melaksanakan kegiatan didesa tersebut.

\section{Daftar Pustaka}

Agunggunanto, E.Y., Arianti, F., Kushartono, E.W., \& Darwanto. (2016). Pengembangan desa mandiri melalui pengelolaan Badan Usaha Milik Desa (BUMDes). JDEB, 13(1), 67-81.

Asti \& Cholid, I. (2018). Persepsi dan partisipasi pemerintah desa dalam perencanaan pengembangan Bumdes di Kecamatan Kendawangan. Jurnal Agribisnis Indonesia, 6(1), 1-14.

Dewi, A. S. K. (2014). Peranan Badan Usaha Milik Desa (Bumdes) Sebagai Upaya Dalam Meningkatkan Pendapatan Asli Desa (Pades) Serta Menumbuhkan Perekonomian Desa. Journal of Rural and Development, 5(1).

Febriyani, H., Nurmalia, R., Lesmana, I. M. I., Ulantari, N. K. W., Dewi, D. P. Y. P., \&

Harmiati, A. A. Z., Zulhakim, A. A., \& Sos, S. (2017). Eksistensi Badan Usaha Milik Desa (BUMDes) Dalam Mengembangkan Usaha dan Ekonomi Masyarakat Desa yang Berdaya Saing di Era Masyarakat Ekonomi ASEAN. Retrieved from: Jurnal Unihaz Bengkulu, Cluster Ekonomi. Setnas ASEAN

Hidayah, U., Mulatsih, S., \& Purnamadewi, Y.L. (2019). Evaluasi Badan Usaha Milik Desa (BUMDes): Studi kasus BUMDes Harapan Jaya Desa Pagelaran, Kecamatan Ciomas, Kabupaten Bogor. JSHP, 3(2), 144-153.

Jamaluddin, Y., Sumaryana, A., Rusli, B. \& Rd. Ahmad Buchari, Rd., A. (2018). Analisis dampak pengelolaan dan penggunaan dana desa terhadap pembangunan daerah. JPPUMA: Jurnal Ilmu Pemerintahan dan Sosial Politik UMA, 6(1), 14-24.

Nugraha, A. \& Kismartini. (2019). Evaluasi penyelenggaraan Badan Usaha Milik Desa (BUMDES) Rejo Mulyo, Desa Gogik, Kecamatan Ungaran Barat Kabupaten Semarang. Dialogue Jurnal Imu Administrasi Publik, 1(1), 43-56.

Rizky, N. (2019). Keberadaan Badan Usaha Milik Desa (BUMDes) Sebagai Penguatan Ekonomi Desa Abiantuwung. Jurnal Ilmiah Akuntansi dan Humanika, 8(1).

Sujarweni, V. W., \& Jaya, I. M. L. M. (2019). Pengelolaan Keuangan Bumdes Sambimulyo di Kawasan Geoheritage "Tebing Breksi” Yogyakarta. Jurnal Ilmiah Padma Sri Kreshna, 1(2).

Suwecantara, I.M., Surya, I., \& Riady, G. (2018). Efektivitas pengelolaan Badan Usaha Milik Desa dalam meningkatkan pendapatan asli desa-studi kasus Bumdes Madani di desa Santan Tengah Kecamatan Marangkayu Kabupaten Kutai Kartanegara. E-Journal Pemerintah Integratif, 6(4), 624-634.

Undang-undang No. 6 Tahun 2014, Tentang Desa 